\title{
Food Safety Issues in International Trade ${ }^{1}$
}

\author{
R.H. Schmidt, R.P. Bates, D.L. Archer, K.R. Schneider²
}

Food safety regulations and their potential use as barriers and restrictions against food products in international trade have been a long-term concern. The issue was only weakly addressed in the original General Agreements on Tariffs and Trade (GATT) in 1947. However the GATT agreements did not formulate nor define an international agreement with regard to food safety. With the formation of the World Trade Organization (WTO) in 1995, specific principles and rules were conceived. These rules, or Sanitary \& Phytosanitary Measures (e.g., SPS Agreement), relate to three primary issues or concerns: food safety, animal health, and plant health. While still controversial, the WTO/SPS Agreement does provide for more detailed control of food safety concerns and for more standardization and harmonization regarding rules and regulations.

\section{The General Principles of the WTO/SPS Agreement}

The general principles of the SPS Agreement have been adapted into the following:

- Members have the right to take sanitary and phytosanitary measures as necessary for the protection of human, animal or plant life or health [Article 2(1)];

- Members have the obligation to ensure that any sanitary or phytosanitary measure is applied only to the extent necessary to protect human, animal, or plant health and is based upon scientific principles and is not maintained without sufficient scientific evidence [Article 2(2)];

- Members must base their SPS measures on recognized international standards, guidelines, or recommendations [Article 3(1)];

- Members may introduce or maintain SPS measures which result in a higher level of protection than would be achieved by measures based on the relevant international standards, guidelines or recommendations if there is scientific justification [Article 3(3)];

- In cases where scientific evidence is insufficient, a Member may provisionally adopt SPS measures on the basis of available pertinent information. In such circumstances, Members shall seek to obtain the additional information necessary for a more objective assessment of risk and review the

1. This document is FSHN034, one of a series of the Food Science and Human Nutrition Department, Florida Cooperative Extension Service, IFAS, University of Florida. Publication: March 2003. Reviewed by: C.A. Sims, Ph.D., professor; and R.E. Turner, Ph.D., associate professor, both of the Food Science and Human Nutrition Department, Cooperative Extension Service, IFAS, University of Florida, Gainesville, FL 32611-0370. Please visit the EDIS Web Site at http://edis.ifas.ufl.edu.

2. R.H. Schmidt, Ph.D., professor; R.P. Bates, Ph.D., professor; D.L. Archer, Ph.D., professor; and K.R. Schneider, Ph.D., assistant professor, all of the Food Science and Human Nutrition Department, Cooperative Extension Service, IFAS, University of Florida, Gainesville, FL 32611-0370.

The Institute of Food and Agricultural Sciences (IFAS) is an Equal Employment Opportunity - Affirmative Action Employer authorized to provide research, educational information and other services only to individuals and institutions that function without regard to race, creed, color, religion, age, disability, sex, sexual orientation, marital status, national origin, political opinions or affiliations. For information on obtaining other extension publications, contact your county Cooperative Extension Service office. Florida Cooperative Extension Service/Institute of Food and Agricultural Sciences / University of Florida / Larry R. Arrington, Interim Dean 
SPS measure accordingly within a reasonable time period [Article 5(7)].

\section{Role of Codex Alimentarius}

General. As shown above, the SPS Agreement clearly mandates that member countries rely on scientific principles as well as recognized international standards, guidelines, or recommendations when applying food safety regulations in world trade. Further, the standards of the FAO/WHO Codex Alimentarius Commission (e.g. Codex Standards) are specified as providing the benchmark. Codex standards, conceived and developed in 1962, have not been mandatory in world trade. Many less developed countries have, however, adopted Codex standards with the intent that they would be more competitive in world trade. However, Codex standards have not been universally adopted by the more developed countries of the world.

Since WTO, various Codex committees have been evaluating and revising the food safety related standards, guidelines, and practices as deemed appropriate with the infusion of more scientific principles. This process has not been an easy task, given the worldwide debates and lack of harmonization in applying these principles in regulations. Several very controversial world trade issues have evolved. These include: beef hormones, milk hormones [recombinant bovine somatotropin (rBST)], bovine spongiform encephalopathy (BSE) (or Mad Cow Disease), genetically modified organisms (GMOs) and genetically modified foods (GMFs), and zero tolerance issues (food additives and pathogenic microorganisms).

Other Legitimate Factors (OLFs). During the evaluation and revision of Codex documents, the phrase Other Legitimate Factors (OLFs) has evolved. The basic intent is that, while science is the key factor in establishing standards, there may be other factors that may also be legitimate. The OLFs identified by Codex include:

- Economically Sustainable. These factors deal with risk assessment and implementation of management strategy that may go beyond pure science (e.g. practically achievable in view of current technology);
- Lack of Appropriate Methods of Analysis. As limits are set for a given contaminant, assessment of the analytical capabilities needs to be addressed;

- Technically Achievable. Is the food safety measure achievable within current technology;

- Additional Safety Factors. These include considerations for the limitations of science in demonstrating a safe level of a contaminant for all levels of society (e.g. accounting for variations in age, diet, metabolism, etc.);

- Technological Need. These factors include benefits or need for substances (e.g. the demonstrated benefit or need of a food additive; safe under "intended use");

- Environmental Concerns. In addition to food safety, impact on environment is considered;

\section{- Animal Health and Welfare Concerns. In} addition to food safety, impact on animal health is considered (many of the objections to BST fall into this category);

- Consumer Concerns. There may be consumer objections beyond safety or science issues (e.g. public perception of hormones in beef in certain countries).

\section{The Precautionary Principle}

When there are "reasonable grounds for concern that a potential hazard may affect the environment or human, animal or plant health, and when at the same time available data preclude a detailed risk evaluation", the European Union has applied what is termed the Precautionary Principle as a risk management strategy in food safety regulations. While not specifically adopted nor defined by the WTO, the basis for its application is derived from Article 5(7) of the SPS Agreement (shown above) and from other international conventions and sources.

The EU Commission has issued its Communication on the Precautionary Principle. The full text is available on-line at: 
http://europa.eu.int/comm/off/com/health_consumer/ precaution_en.pdf.

It is the intent that the Precautionary Principle be considered within a structured approach to risk analysis including: risk assessment, risk management, risk communication. However, procedures used in its application differ from those normally used in more scientific risk analysis.

The general principles of implementing the Precautionary Principle include:

- Proportionality. Measures based on this principle must not be disproportionate to the desired level of protection and must not be aimed a zero risk.

- Non-discriminatory. Measures should be non-discriminatory and not arbitrary in implementation.

- Consistency. Measures should be consistent with other adopted measures.

- Examination of benefits and costs of action and lack of action. Economic cost-benefit analysis should be done.

- Examination of scientific developments. Measures should be maintained as long as scientific data are inadequate.

The issue of when and how to use the Precautionary Principle, both within the European Union and internationally, is giving rise to much debate, and to mixed, and sometimes contradictory views. For example, this controversial principle has been the backdrop for the extra-labeling required for foods derived from GMOs or GMFs in Europe. The goal in applying and implementing the Precautionary Principle is to achieve the desired protection level regarding a particular substance without it being a disguised form of protectionism.

\section{Summary and Conclusions}

It is refreshing to note that scientific principles have been elevated to a position of importance in setting international standards for food residues. Codex adopted the Statements of Principle in 1995, which defines the procedures used. Further, a universal residue limit has been set for one controversial issue (beef hormones). However, other social, technical, and cultural factors and related OLFs make application of these principles difficult and differences between Europe, North America, and less developed nations are still unresolved.

The current trend towards the use of labeling (e.g., genetically modified corn/soya; hormone-free meat/milk; etc.) does provide an opportunity for consumers to express choice, but it places additional burdens upon the industry. Further, enforcement of labeling violations may be difficult as the statements are difficult to prove.

Considerable progress has been made in recent years with regard to minimizing non-tariff trade barriers surrounding food safety issues and harmonizing global food regulations. However, varying levels of acceptance make universal decisions difficult. Enough issues remain to keep politicians, scientists, and regulators engaged for several years to come.

\section{References}

\section{Anon. 2000. Communication from the} commission on the precautionary principle. Brussels, 02.02.2000.

http://europa.eu.int/comm/dgs/health_consumer/ library/pub/pub07_en.pdf.

2. Jukes, D. 2000. The role of science in international food standards. Food Control 11:181-194. 